\title{
Tela encolada y cabello natural como técnicas aplicadasa la escultura tardogótica
}

\author{
Francisco Javier Casaseca García
}

\begin{abstract}
Resumen: El estudio de un conjunto de crucificados del oeste de Castilla y León, de características formales similares, y enmarcados en la escuela escultórica centroeuropea, muestra que ya a finales del gótico y comienzos del renacimiento, se utilizó la tela encolada y el cabello natural como recursos plásticos. Aparecen antes de lo que se ha planteado hasta el momento, ya que habían sido considerados exclusivos de la teatralidad barroca. Se analizan sus aspectos formales y sus enormes analogías para establecer una tipología que los agrupe y defina, y se concluye con una aportación teórica para explicar el significado del uso de tales recursos en el momento de su creación.
\end{abstract}

Palabras clave: Tela encolada; Cabello natural; Peluca; Escultura Tardogótico; Técnica escultórica;Crucificado.

\section{Encolagem e cabelo natural como técnicas aplicadas na escultura tardo-gótica}

Resumo: O estudo de um conjunto de Cristo crucificado, do oeste de Castilla e León, com similares características formais e integrado na escola escultórica do centro da Europa, revela que já nos finais do Gótico e início do Renascimento, a tela encolada e o cabelo natural eram recursos plásticos já utilizados. Estes são anteriores ao que até ao momento se pensava serem exclusivos da teatralidade barroca. Analisam-se os aspectos formais e as profundas analogías, para establecer uma tipologia que os agrupe e os defina, e conclui-se com uma contribuição teórica, para explicar o significado do uso de tais recursos, no momento da sua criação.

Palavras-chave: Encolagem; Cabelo natural; Peruca; Escultura tardo-gótica; Técnica escultórica; Crucificado.

\section{Sizing canvas and natural hair as applied techniques in the Late Gothic sculpture}

Abstract: The study of a set of crucified Christs located in western Castilla y León with similar formal characteristics and framed in the Central European sculptural tradition, has led to the hypothesis that already by the late Gothic and early Renaissance, glued cloth and natural hair were used as artistic resources. They appear earlier of what it's been thought as they were as they were considered exclusive of the baroque theatricality. Its formal aspects and huge analogies are analyzed to establish a typology that groups them and define them, and concludes with a theoretical contribution to explain the significance of using such resources at the time of its creation.

Keywords: Glued cloth; Natural hair; Wig; Sculpture; Late Gotic; Sculptural technique; Crucified.

En este artículo se presenta el estudio ${ }^{1}$ realizado sobre las técnicas escultóricas menos conocidas de un conjunto de seis esculturas renacentistas de cristos crucificados de similares características, tratando de mostrar su contemporaneidad y su gran parecido, que se dijeran salidos de la misma mano o taller, además de evidenciar aspectos formales diferenciadores como la talla y aspectos formales de la policromía. Estilísticamente poseen rasgos de la tradición escultórica germánica y flamenca, aunque adaptados a las particularidades que predominaban en Castilla entre los siglos XV y XVI. Se encuentran diseminados al oeste de Castilla y León, en las provincias de Salamanca, León y Palencia. Se profundiza en los aspectos técnico, formal y expresivo del empleo de la tela encolada y del cabello natural. Estos son recursos escultóricos poco estudiados y a menudo malin- 
terpretados, pero que como veremos son habituales desde finales del gótico para expresar valores estéticos contrapuestos a los que ofrece la talla en madera.

Desde la perspectiva de la conservación y restauración se indaga con más profundidad en aspectos técnicos y materiales de las esculturas, empleando dos metodologías complementarias. Por un lado, el examen directo de las esculturas en su entorno, para determinar elementos constitutivos, sistemas de construcción, materiales y técnicos empleados. Así se estudian los estratos polícromos presentes en cada obra tratando de determinar la cronología de cada uno y hasta qué punto una policromía única corresponde forzosamente al original. Y por otro lado se analizaron los datos de los informes previos y posteriores a los tratamientos de conservación y restauración a los que se hayan sometido las esculturas, para establecer la cronología de los materiales presentes y la historia material de las mismas. En algunos casos han colaborado los restauradores que las han intervenido, en otros se han tomado los datos directamente de los informes de restauración. Además se han tenido en cuenta los usos y funciones para los que estas esculturas fueron realizadas como factores determinantes de su significado e intencionalidad. Se han estudiado en primer lugar aquellos que han servido de modelo a los otros, y después los que se consideran copia de los anteriores.

Tanto en Italia como en España, se hicieron esculturas de crucificados y santos en madera y tela encolada, al menos desde el siglo XV (Speranza 2007). A pesar de la calidad de muchas de estas obras realizadas en nuestro país, no se les ha prestado la atención que merecen en toda su dimensión material. Tan solo se han hecho estudios aislados que parten de la idea preconcebida de que la escultura en madera de los siglos XV y XVI se realizaba únicamente con madera, y que cualquier otro material escultórico presente era un añadido posterior al momento de su creación, situación atribuida normalmente a los excesos del Barroco.

Al estudiar el empleo de tela encolada, se han encontrado ejemplos muy antiguos de época gótica, como el Cristo Negro de la Concatedral de Cáceres, o a caballo entre el gótico y el Renacimiento, como el Cristo de Ventosa en Santa María del Azogue en Benavente (Zamora) ${ }^{2}$. Pero sobre todo, se pudo establecer una relación entre un grupo de crucificados tardogóticos basada en su similitud estilística, técnica y formal, contemporáneas en el tiempo. Se trataba de cristos tan parecidos que se dirían salidos de la misma mano o taller. La mayoría de ellos han pasado desapercibidos, y sólo han conseguido salir de su ostracismo al ser recuperados para las celebraciones de Semana Santa en sus lugares de origen, diseminados al oeste de Castilla y León, en las provincias de Salamanca, León y Palencia: el Cristo de la Agonía Redentora en Salamanca, el Cristo de la Salud o de San Leonardo en Alba de Tormes (Salamanca), el Bendito Cristo de Villaquejida (León), el Cristo de la Agonía en Sahagún de Campos (León), el Cristo de la Misericordia y el Santo Cristo del Otero ambos en Palencia. Este parecido formal ha permitido establecer la hipótesis del empleo habitual de la tela encolada y del cabello natural, como una forma de hacer escultura a finales del XV y principios del XVI. De forma pionera, se estudia la tela encolada, el cabello natural en pelucas y barbas postizas, y las cuerdas para los regueros de sangre, como recursos escultóricos expresivos, considerados elementos originales surgidos de la voluntad creativa de su autor o autores.

\section{Cristo de la Agonía Redentora}

Está situado en el crucero norte de la Catedral Nueva de Salamanca. Procede del convento de las Isabeles de la ciudad, afectado por la desamortización de Mendizábal, por la que tuvieron que exclaustrarse y entregar la imagen al Cabildo Catedral de Salamanca en 1836. Desde 1987 sale en procesión en la Semana Santa salmantina2. Imagen de Cristo crucificado de tamaño natural ( $175 \mathrm{x}$ $165 \times 35 \mathrm{~cm})^{3}$, representa el momento de la expiración. Es de madera de cedro ${ }^{4}$ tallada, salvo parte del paño de pureza que es de tela encolada, policromado, y con peluca de cabello natural en la 
cabeza. Tiene además corona de espinas metálica, y cruz sustituida por una nueva recientemente. Está clavado a la cruz con tres clavos, y su pie derecho monta sobre su izquierdo. La herida del costado está inclinada y se sitúa entre las costillas del costado bajo. De frente las piernas dibujan un ligero arqueamiento hacia afuera que parte de la cadera y se cierra en los pies. Tiene el pecho hinchado, haciendo que se marquen las costillas. De perfil la figura describe un zigzag, donde los brazos están estirados hacia atrás, la cabeza y el pecho hacia delante, la cintura retrocede pegada a la cruz, las piernas están flexionadas adelantando las rodillas, y los pies pegados a la cruz. Los brazos se mantienen casi horizontales como asiéndose a la cruz. Su anatomía está marcada y detallada y, en palabras de Gómez-Moreno (1967), es "producto de un estudio exacto y minucioso del natural", correspondiente a un cuerpo magro, bien proporcionado, y curtido por los rigores del trabajo y el esfuerzo. La musculatura es seca, definida sin excesos, dejando ver el esternón, las costillas, las rodillas y los tobillos. Tiene talladas venas y tendones en relieve, que se entrecruzan sinuosamente en forma de retícula por el cuello y las extremidades, aumentando la sensación de tensión. Encima de las rodillas, los talones y en los bordes de la planta de los pies se aprecian pliegues paralelos en la piel enjuta. La cabeza está inclinada hacia su derecha y su rostro agónico y agotado conmueve por su patetismo. Sus ojos hundidos y entreabiertos, las pupilas elevadas hacia el cielo en el último momento antes de exhalar, y en la boca abierta tiene tallados con detalle dientes y lengua. La policromía es gris rosada con cierta tendencia cetrina, modelando volúmenes, venas y golpes. Hay repartidos cientos de latigazos por toda la piel, de trazos cortos y cruzados en tonos azulados y oscuros con una línea rojiza, como si la piel se hubiera abierto y sangrara. De las heridas de la frente, el costado, manos y pies mana sangre con moderación. En las axilas y bajo el labio inferior hay un peleteado que dibuja el vello de esas zonas, y caen lágrimas de los ojos en forma de regueros de color lechoso. La cabeza es lisa, preparada para recibir peluca, que se ciñe a la frente con la corona de espinas metálica. Tuvo barba postiza, como demuestran imágenes fotográficas (Gómez-Moreno 1967: 203) anteriores a las intervenciones que ha sufrido ${ }^{5}$, donde se observan restos de cabellos y manchas oscuras del adhesivo usado para sujetarla. El aspecto lampiño actual no es propio de las representaciones iconográficas del crucificado.

El perizonium está formado por una larga banda de tela que cubre la cintura y parte de los muslos, hecho de tela encolada, con un drapeado de pliegues menudos, como un paño mojado y arrugado pegado al cuerpo. El sobrante, de madera tallada, se anuda airosamente a su izquierda, con un extremo del lazo hacia arriba y otro más grande hacia abajo, con un drapeado movido, de pliegues que parten del nudo central y se quiebran como agitados por el aire. Está policromado en blanco con dos estratos, el inferior aparece amarillento, y el superior tiene matices agrisados que modelan el drapeado, pudiendo tratarse de la capa de color con algunas lagunas por las que se deja ver una preparación amarillenta. Tiene un vivo de bordado español o isabelino con motivos circulares repetidos y enmarcados por líneas rectas de color carmín en el anverso y azul en el envés. La tela encolada es de tafetán de lino de densidad media, y se encuentra en el mismo nivel que la madera tallada, sobre la que se aplicó para después preparar y policromar el conjunto. El lazo tallado se ensambla al resto de la imagen con clavos de hierro, como se comprobó durante las restauraciones mencionadas ${ }^{6}$.

En el Cristo de la Agonía Redentora no hay idealización, no es un modelo o estereotipo de Cristo en la cruz, sino que es un cuerpo concreto, palpable, que tiene sus rasgos individuales e imperfecciones, que lo hacen único e identificable, y que el escultor se ha esforzado en retratar. Tiene un elevado nivel de detalles expresivos, anatómicos y polícromos, que tienen su correlación en el uso de cabello natural y de tela encolada como recursos para desarrollar el naturalismo que la imagen transmite con fuerza. Para algunos autores "la peluca y un sudario moderno de trapo encolado" desfiguran y hacen "desmerecer artísticamente la expresión de esta imagen" (Gómez-Moreno 1967; Sánchez 1993), pues suponen que son añadidos. Blázquez Vicente (2001) lo atribuye a Juan de Balma- 
seda, por su parecido formal con otros crucificados de este autor, y cronológicamente lo sitúa en torno a 1525.

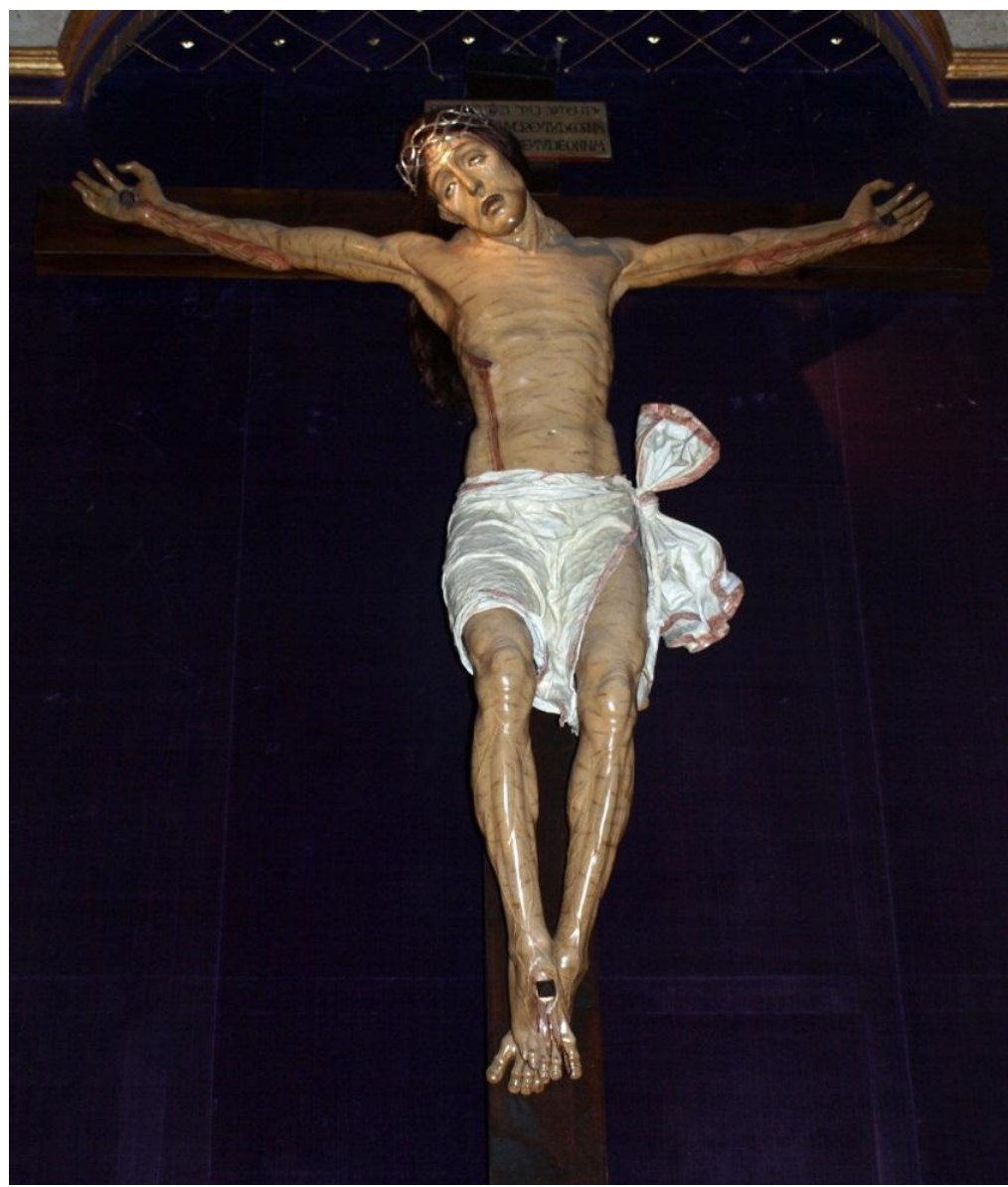

Figura 1. Cristo de la Agonía Redentora $(175 \times 165 \times 35 \mathrm{~cm})$ Catedral Nueva, Salamanca

\section{Cristo de la Salud o de San Leonardo}

El Cristo de la Agonía Redentora puede que sea una copia del Cristo de la Salud o de San Leonardo (Rodríguez 1922: 34-35) de la iglesia de San Pedro de Alba de Tormes, mandada hacer por la Universidad de Salamanca ${ }^{7}$ y con él se establecen paralelismos formales muy claros. Este soberbio crucificado tiene todos los indicativos para ser el predecesor y el modelo para el Cristo de la Agonía Redentora de Salamanca. Ambos son idénticos en la postura, las proporciones, la anatomía y los rasgos expresivos del rostro, utilizando cabello natural en la peluca. No es así en la barba, ni el perizonium, que en el Cristo de la Salud están tallados en madera con gran virtuosismo. Las diferencias técnicas pueden deberse a que el autor de este cristo fue capaz de resolver en madera tallada aspectos expresivos para los que otros autores necesitaron emplear la tela encolada o la barba posti$z a$, o bien a que desconociera estas técnicas. Este paño de pureza tiene pliegues muy finos, horizontales y algo quebrados, y el lazo que se anuda a su izquierda sigue el mismo esquema que el Cristo de la Agonía Redentora. En el Cristo de la Salud las venas y los tendones aparecen tallados en relieve bastante acusados y detallados. Y la policromía también es semejante al de la Catedral sal- 
mantina, incluso en las lágrimas blancas, salvo porque se encuentra algo oscurecida por la suciedad y barnices. Su deuda estilística con la escultura alemana y flamenca de finales del siglo XV y principios del XVI es patente ${ }^{8}$. Siendo ambas obras excepcionales, el Cristo de la Salud puede haber servido de modelo para el de la Agonía Redentora, pues es superior escultóricamente, y según Gómez Moreno, anterior en el tiempo -siglo XV-, y quizá también modelo para los demás cristos que analizamos en el presente artículo.

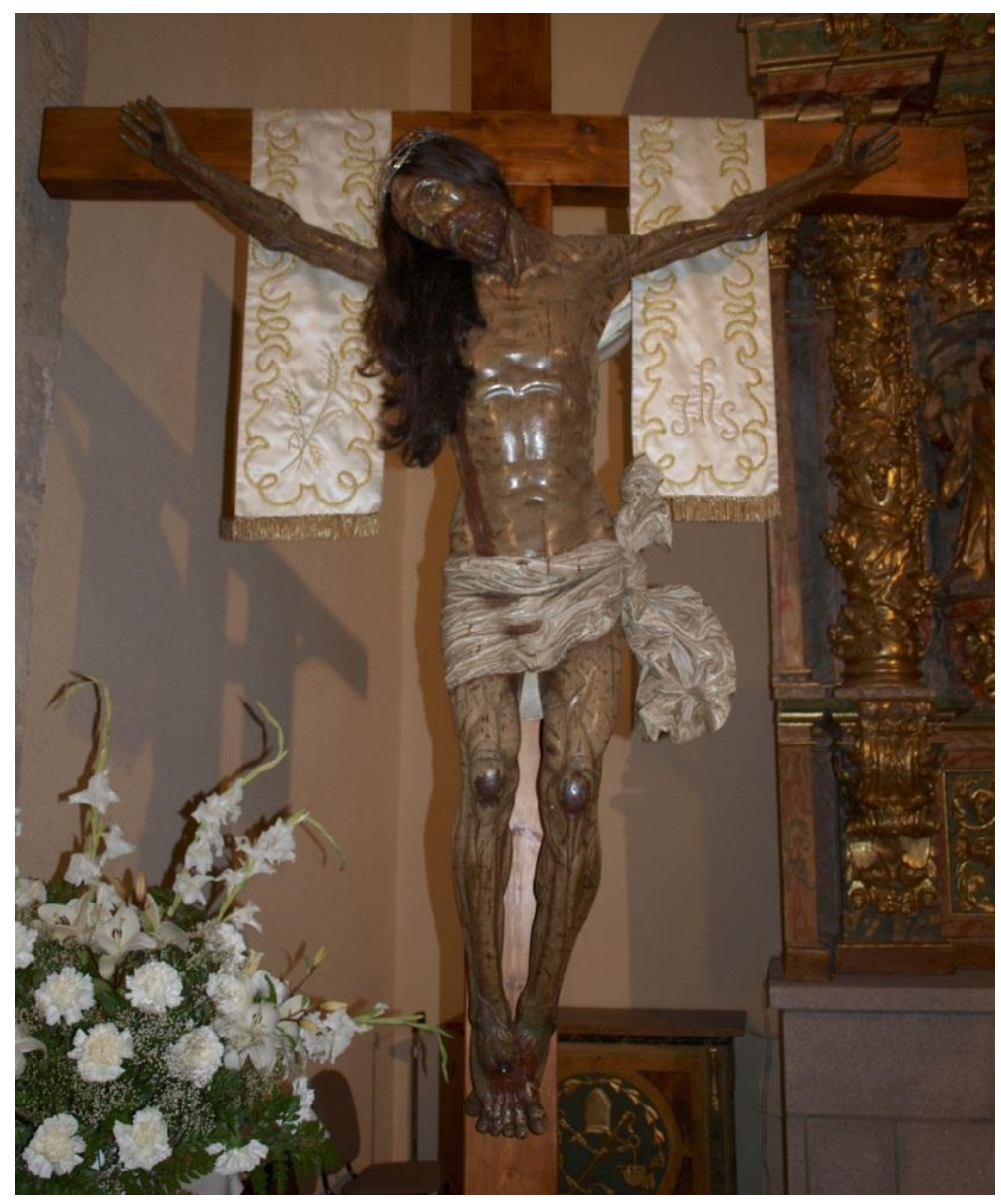

Figura 2: Cristo de la Salud o de San Leonardo $(178 \times 168$ × 35cm) Iglesia de San Pedro, Alba de Tormes (Salamanca).

\section{Bendito Cristo de Villaquejida}

El Bendito Cristo de Villaquejida es una imagen dramática un crucificado que se venera en su camarín del retablo mayor de la iglesia parroquial del Santo Cristo y de Santa María de las Heras de Villaquejida (León), y que goza de una enorme devoción en toda la comarca, manifestándose en la fiesta que se celebra el 14 de septiembre en su honor. Es de tamaño natural (172 x 164 x 34cm) y representa el momento de la agonía final. Gómez Moreno lo describe como "muy seco pero bien hecho" (Gómez-Moreno 1925: 509). Es prácticamente igual al Cristo de la Agonía Redentora de Salamanca en todos sus aspectos formales. Postura y contorsión de la figura, tipo de anatomía, musculatura seca, tensión de los miembros, venas y tendones tallados en relieve -aunque con menor detalle-, pliegues y arrugas en la piel. Posición de la cabeza e idéntico rostro agónico, boca exhalante y ojos vueltos hacia arriba. La policromía también es de tonalidad similar a la de la Agonía 
Redentora, pero peor conservada, a pesar de la restauración de $2007^{9}$. No presenta tantas marcas de tormento, ni el peleteado ni las lágrimas blanquecinas en los ojos de aquel. Los regueros de sangre son algo más abundantes con gotas que discurren serpenteantes, y la herida del costado es muy similar. La cabeza también es lisa y redonda, pensada probablemente para recibir peluca. Ésta se ciñe a la cabeza con una corona de espinas independiente tallada en madera, abultada, de tallos gruesos trenzados regularmente, que en algunas partes son prismáticos, y con espinas gruesas que siguen la dirección del trenzado. Esta corona está policromada en verde oscuro, y es muy parecida a la que presenta el crucificado del calvario del retablo mayor de la Catedral de Palencia, de Juan de Balmaseda. Al ser un elemento independiente, se podría extrapolar que la imagen fue hecha para tener peluca desde el principio, al igual que la barba de cabello natural, de la que carece en la actualidad y que no ha sido reintegrada en la reciente restauración. En las fotografías antes de la intervención (Parrado 1979: 151) se aprecian manchas blanquecinas y oscuras donde se ubicaría la barba, consecuencia de la degradación del adhesivo empleado para la sujeción de ésta sobre la policromía.

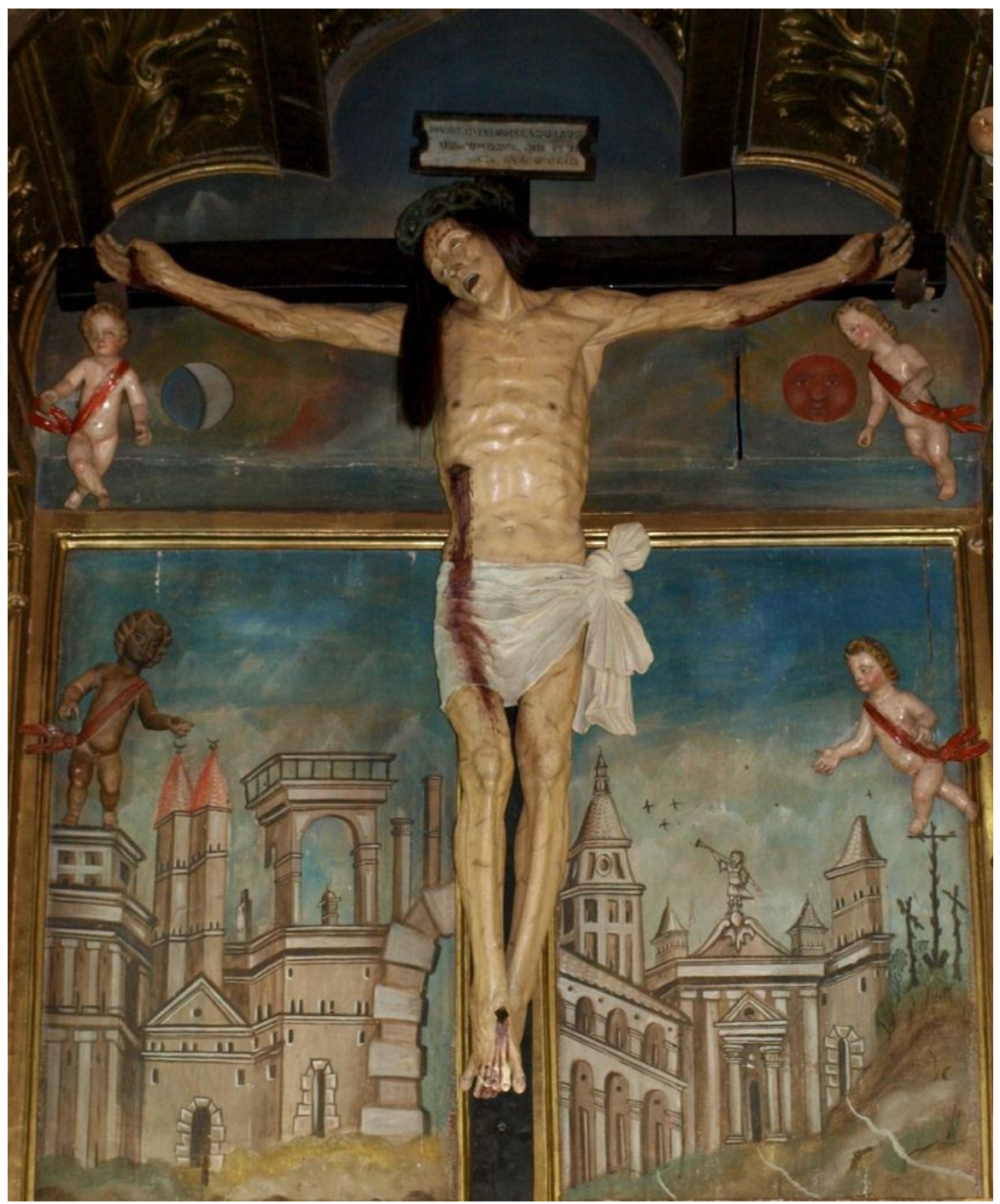

Figura 3. Bendito Cristo de Villaquejida $(172 \times 164$ × 34cm) Iglesia del Santo Cristo y de Santa María de las Heras, Villaquejida (León). 
El perizonium del Cristo de Villaquejida está formado por una banda de tela encolada que cubre la cintura y los muslos hasta la mitad, con drapeado sencillo y aspecto de tela mojada pegada al cuerpo, de pliegues finos, horizontales y diagonales que concurren en el lazo tallado en madera anudado a su izquierda, cuyos extremos sobrantes cuelgan ordenada y escalonadamente con pliegues delgados, repetidos y paralelos. En la parte inferior tiene ondulaciones y quiebros angulosos como movidos por el viento. Se adosa al resto del perizonium continuando los pliegues formados en tela encolada. El tejido de la tela encolada es tafetán delgado de lino, de trama cerrada y densa que no se deja apreciar a través de la policromía en temple ${ }^{10}$ blanco y sin motivos decorativos que la recubre. En la parte posterior la tela encolada presenta los bordes parcialmente quemados, y están ligeramente despegados de los muslos dejando ver la madera sin policromar. Este hecho facilita la reconstrucción del proceso de elaboración. La tela encolada se aplica sobre la talla y luego se policroma toda la escultura conjuntamente, apreciándose en el detalle del borde de la tela encolada sobre el que se monta ligeramente la carnación siendo ésta la última capa en aplicarse, de tal manera que el blanco del perizonium podría corresponder a una capa de preparación aplicada a toda la escultura y dejada "en reserva" como color del tejido.

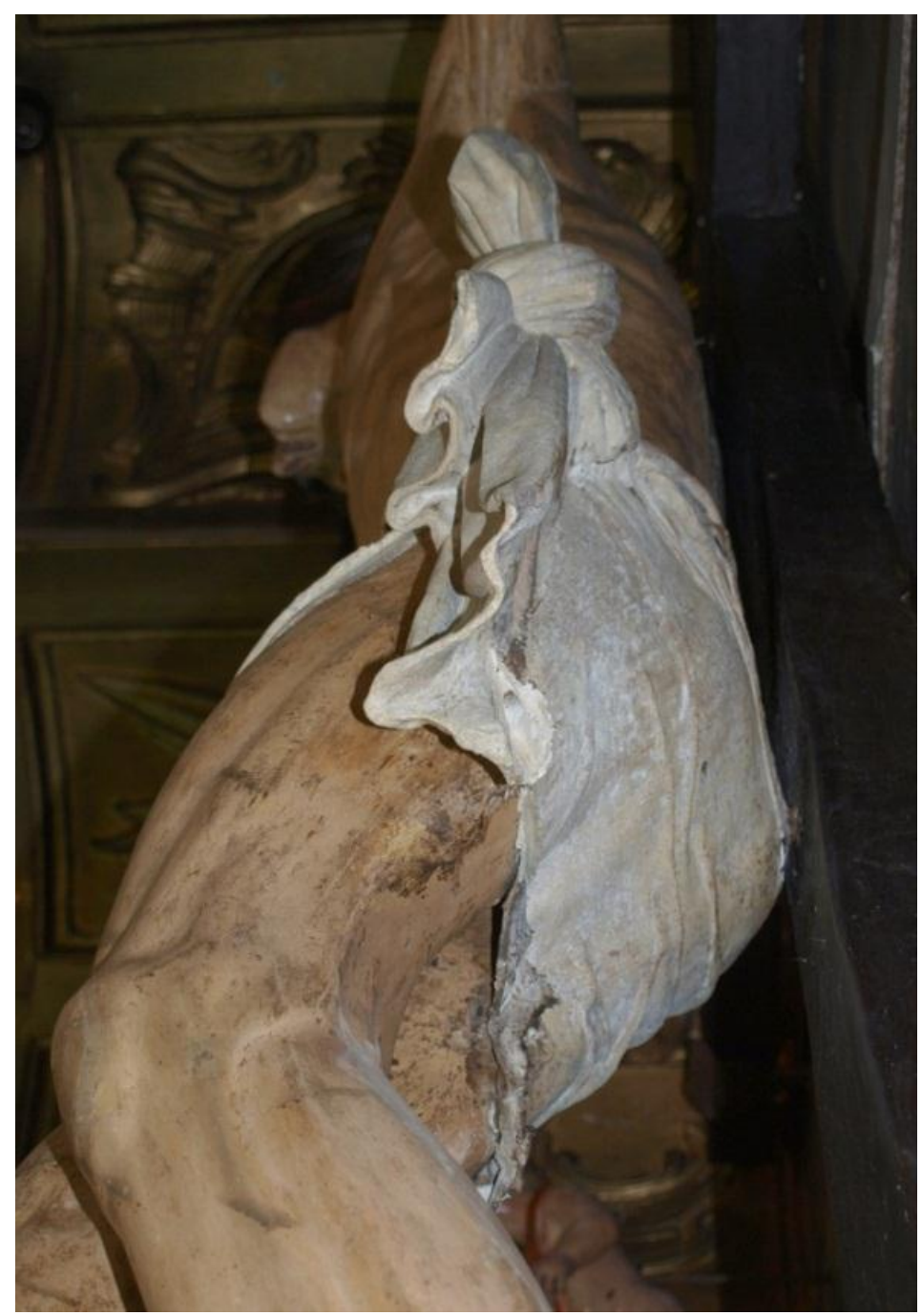

Figura 4. Detalle del perizonium del Bendito Cristo de Villaquejida. Encuentro entre la tela encolada y el lazo tallado en madera. Se aprecia madera sin policromar bajo la tela encolada despegada del muslo. 
Parrado del Olmo (1979) dice que es una escultura de buena calidad y se lo atribuye a Juan de Balmaseda, "nos recuerda por su canon, tipo de lazada del paño de pureza e inclinación de la cabeza, al crucifijo del retablo de la Capilla del Cristo de la Catedral de León", pudiéndolo realizar entre 1524 y 1527. Según este autor, el cabello natural de la peluca y barba parecen ser originales, sin aportar más datos.

\section{Cristo de la Agonía}

El Cristo de la Agonía está ubicado en el museo del Monasterio de Santa Cruz de las Madres Benedictinas en Sahagún de Campos (León), procedente de la iglesia de la Peregrina ${ }^{11}$, donde tuvo mucha devoción y fama de milagroso, llegando al monasterio hace más de 60 años, según las monjas. Es una escultura de Cristo crucificado en su agonía, en tamaño natural (170 x $168 \times 38 \mathrm{~cm})$. Formalmente tiene bastantes similitudes con las otras tallas estudiadas, aunque con ciertos matices. Vista de frente la figura es más sinuosa inclinando el torso y las piernas, con el punto de inflexión en la cadera. Los brazos son horizontales y paralelos al patibulum. La musculatura es menos seca, sin venas talladas, ni pliegues en la piel. La cabeza tiene la misma inclinación, y el rostro agónico es más redondo, mostrando los dientes en la boca exhalante. Los ojos están más abiertos mirando hacia arriba, y tiene talladas las orejas de pequeño tamaño, que asoman por debajo del cabello, dotando al conjunto de un aspecto primitivo y gotizante. La oscura policromía exterior tiene pocas señales de la flagelación, salvo ataduras en tobillos y muñecas, y azotes aislados en brazos y piernas. Presenta tonalidades verdosas en las rodillas, pies, manos, nariz y pómulos, muy habitual en las carnaciones de crucificados barrocos. Los regueros de sangre de las heridas de las manos, de los pies y del costado son ramificaciones largas, terminadas en gotas gruesas y están elaborados con cuerdas lacradas y policromadas ${ }^{12}$. Bajo la tela encolada que hay entre las piernas se aprecia otra policromía más clara, de tonalidad gris rosado, también visible en las lagunas que presentaba antes de la intervención, y que podría tratarse de la policromía original. La herida del costado está ubicada más arriba que en los otros. La cabeza también es lisa con una capa de preparación sobre la que se ciñe la peluca con una corona de espinas hecha de soga trenzada, encolada y policromada, con largas espinas de madera dispuestas en sentido radial, como los fulgores de una aureola, que ocasionan abultamientos alargados al clavarse bajo la piel de la frente. Tiene barba y cejas de cabello natural, detalle éste último que sólo aparece en este cristo, y que han sido restaurados. El perizonium tiene un extraordinario parecido con el del Cristo de Villaquejida del que pudiera ser copia, pues la parte del paño que cubre la cintura y muslos tiene un drapeado similar, anudándose con el mismo tipo de lazada tallada en madera y con un drapeado parecido, con algo más de movimiento. El tejido de la tela encolada es de lino con ligadura de tafetán, delgado, de trama cerrada y densa, apreciable en una pequeña laguna que tiene en el borde de la parte posterior. El lazo de madera tallada presenta su parte trasera lisa sin tallar, indicando que su visión es frontal. Está policromado con temple blanco, y decorado con un filo negro y un vivo de oro, apreciándose una policromía subyacente, también blanca, de acuerdo a las fotografías de la intervención de 2007 facilitadas por la restauradora Marta Eva Castellanos. De tal modo se pueden relacionar las dos policromías de las carnaciones con las dos policromías del perizonium. La policromía externa, más oscura en las carnaciones y con decoración en negro y oro en el borde, de época barroca, y la subyacente más clara y grisácea en las carnaciones y blanca en el perizonium. La cruz es lisa y sin cartela, similar a la del Cristo del Otero. 


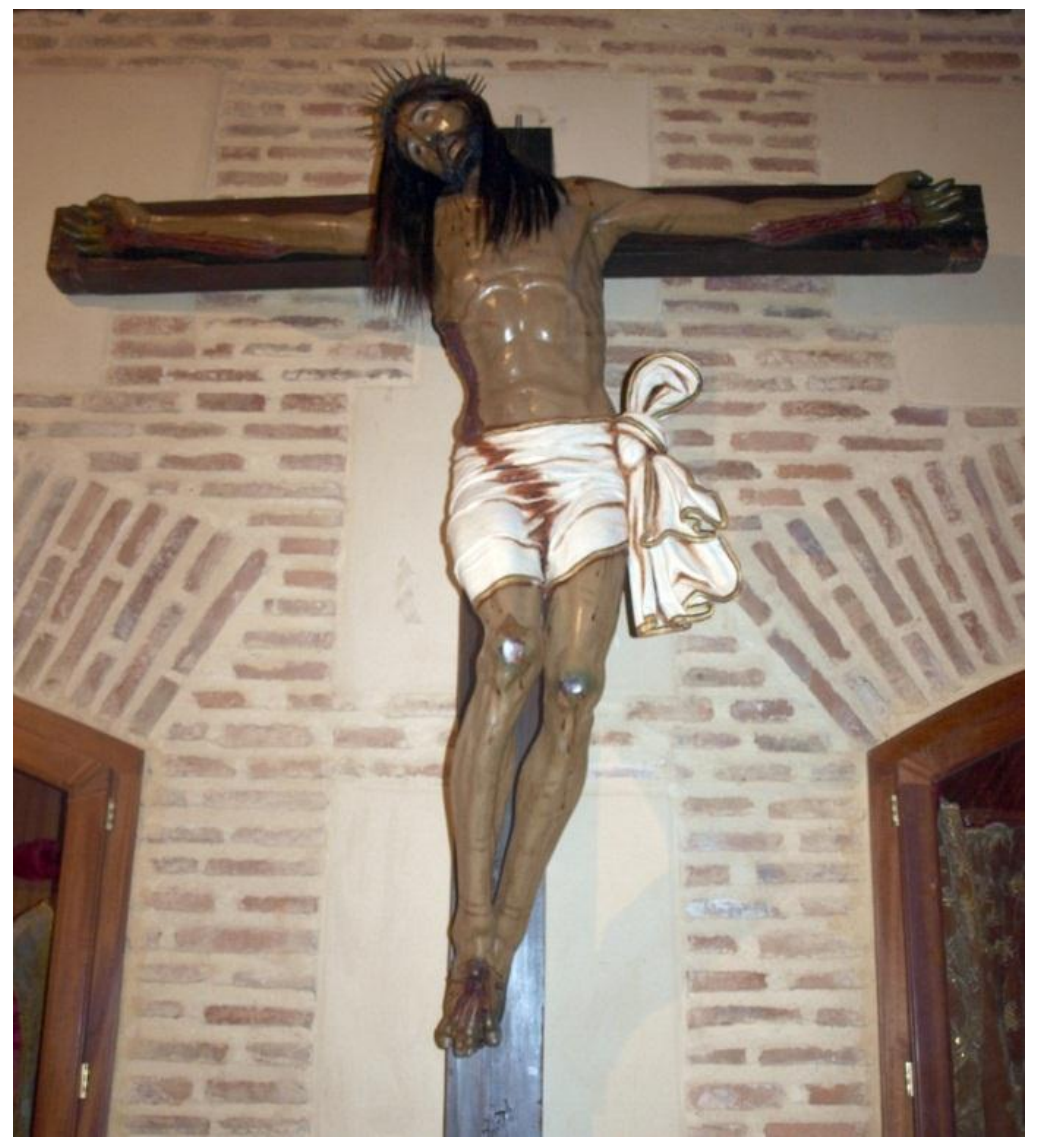

Figura 5. Cristo de la Agonía ( 170 x 168 x 38cm) Museo del Monasterio de Santa Cruz de las Madres Benedictinas, Sahagún de Campos (León).

Todo indica que el Cristo de la Agonía es de comienzos del siglo XVI, y sus características formales coinciden con las de los otros cristos en un alto porcentaje, pero con leves diferencias debidas a una intervención en época barroca, cuando se cubrió la policromía original aplicando la actual más oscura y embotando detalles de la talla, pero que no ocultaron las características que denotan su primitivismo.

\section{Cristo de la Misericordia}

El Cristo de la Misericordia se encuentra en su retablo de una capilla lateral de la nave del Evangelio de la iglesia parroquial de Nuestra Señora de la Calle o de la Compañía en Palencia. Fue donada por el obispo Pedro de Lagasca (1551-1561) a los jesuitas del templo donde se conserva actualmente (Blázquez 2001: 27). Desfila en Semana Santa con la Hermandad del Santísimo Cristo de la Misericordia desde el año 1943 (Gómez 2005: 92-93). Es un crucificado de tamaño natural (179 x 167 x $30 \mathrm{~cm}$ ), en el momento de la agonía, y tallado en un embón macizo sin ahuecar según las radiografías realizadas en la última restauración ${ }^{13}$. Guarda una estrecha similitud con los otros casos estudiados $^{14}$, sobre todo con el de Villaquejida (Parrado 1979: 151), del que parece ser una copia o aquel de éste. Por no reiterar su descripción señalaremos únicamente aquellos matices que distinguen al Cristo de la Misericordia del Cristo de Villaquejida: anatomía más marcada, sobre todo en las costillas. La herida del costado está más alta y la sangre que mana de ella, de las manos y los pies está hecha con cuerdas encoladas, lacradas y policromadas al igual que en el Cristo de la Agonía de Sahagún de Campos. El paño de pureza está realizado completamente con tela encolada y no tiene 
ninguna parte en madera tallada a diferencia de los ya estudiados, dando un paso más en el uso de un recurso realista que aleja a la obra de la idealizada concepción gótica de lo divino -que se podría asociar con la tela tallada en madera- de tal manera que, por medio del uso de la tela encolada en todo el perizonium, acerca la obra al aquí y al ahora humanizándola. El nudo del lazo que está a su izquierda, cae vencido por el peso y blandura del tejido, de forma natural, ya no es rígido y anguloso como los tallados en madera. El tratamiento del drapeado de la tela encolada es más escultórico que en Villaquejida, combinando grosores y direcciones diferentes en los pliegues, jugando con la profundidad. El naturalismo se acentúa con la insinuación de una turgencia en la zona de los genitales bajo la tela encolada, que resalta el efecto de tela mojada pegada al cuerpo, lo que da mayor humanidad y realismo a la escultura. Está hecho con una tela de tafetán de lino, de trama cerrada, y grosor mediano-fino, que puede apreciarse en el revés de un pliegue del lazo. La policromía es blanca sin decoraciones, con matices azulados y grises para modelar los pliegues. Tiene peluca y barba de cabello natural, como el de Sahagún de Campos, pero las cejas están pintadas. La barba es más larga y ondulada, con un peleteado en la policromía bajo el labio inferior para atenuar el contraste, similar al del Cristo de la Agonía Redentora de Salamanca. La corona de espinas que ciñe la peluca está hecha de rama de espino. La carnación es muy similar a la de Villaquejida y la de Salamanca, remarcando las heridas de la flagelación. A los pies de la cruz hay una representación del calvario con piedras, una calavera, dos fémures y otros huesos, en madera tallada y policromada, y que recuerda al de Balmaseda del retablo mayor de la catedral de Palencia.

El conjunto es una escultura de enorme calidad artística y en un estado de conservación excelente, y que parece conservar una apariencia muy parecida a la original del siglo XVI. Diversos autores (Camón 1961: 160) la han atribuido a Juan de Balmaseda ${ }^{15}$, por su parecido formal con el calvario del retablo mayor de la catedral de Palencia, obra suya documentada, y a partir de la cual se le atribuyen esta y otras obras.

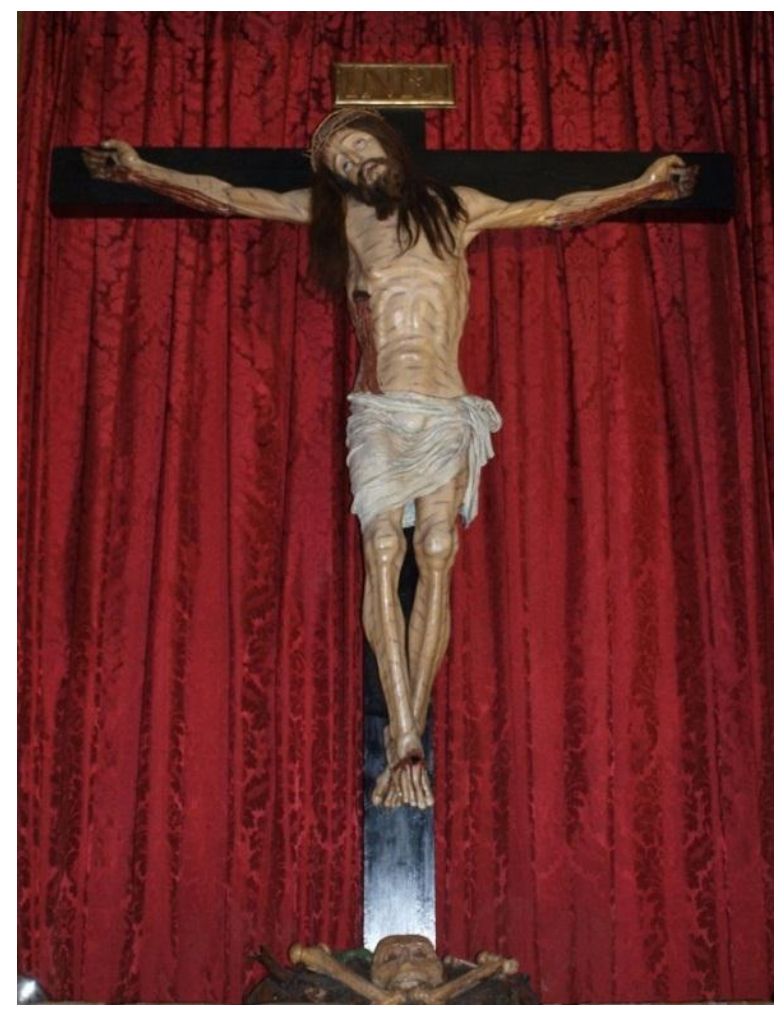

Figura 6. Cristo de la Misericordia $(179 \times 167 \times 30 \mathrm{~cm})$ Iglesia de Nuestra Señora de la Calle o de la Compañía, Palencia. 


\section{Santo Cristo del Otero}

El Santo Cristo del Otero goza de una gran devoción en la ciudad, y está rodeado de hechos milagrosos documentados desde el siglo XV (Fernández 2009: 28). Mide 163 x 153 x 30cm, y representa a Cristo agonizando en la cruz. Se encuentra en un sencillo retablo del altar mayor de la ermita del Otero en Palencia. Artísticamente está al mismo nivel que el Cristo de la Misericordia, y formalmente son casi idénticos en la postura, proporciones, anatomía, rasgos expresivos, y empleo de cabello natural, salvo en algunos detalles. La cabeza está ligeramente más levantada, y la mirada se eleva al cielo. Las piernas están más juntas, y más verticales sin describir arqueamiento. Viste un faldellín o tonelete de terciopelo azul, pues ha perdido el perizonium escultórico de tela encolada ${ }^{16}$, del que queda su huella y que ha permitido estudiar el sistema constructivo original. Bajo el faldellín la zona pélvica tiene tallado un bulto que al cubrirlo con la tela encolada insinúa los genitales como en el de la Misericordia. El policromado desde la cintura hasta donde empiezan los muslos está incompleto pudiéndose leer los estratos que componen la carnación, tal y como sucede en los demás casos estudiados, donde aparece madera sin policromar bajo la tela encolada y en zonas recónditas de difícil acceso para los pinceles. En esta zona pélvica se aprecia la superposición de tres estratos de policromía diferentes, sobre una preparación blanca. El inferior es de color rosado grisáceo -que corresponde con el estrato original-, el intermedio de cierta calidad es más claro y anaranjado, y correspondería a época barroca, y el superior es verdoso y está aplicado groseramente y selectivamente en ciertas partes para ocultar desperfectos de los anteriores, observables por el escalón superficial. Además invade partes de la zona pélvica que están en madera desnuda sin policromar, lo que hace sospechar que se aplicó cuando el perizonium de tela encolada ya se había eliminado. A su izquierda, la superficie de madera sin policromar es lisa y plana probablemente por ser la zona de unión a "maderas vivas" con el lazo hecho en madera tallada, reforzado por medio de clavos que han dejado su huella en forma de tres orificios -si aceptamos que el lazo fuera de madera siguiendo el modelo de los de Salamanca, Villaquejida y Sahagún. La policromía intermedia barroca presenta regueros de sangre y oculta pequeñas lagunas en las partes frontales de la carnación original. El cabello natural de la peluca y de la barba está desordenado y degradado, desprendiéndose a mechones, y la peluca se ceñía al cráneo liso con una corona, hoy desaparecida. Fernández Morate (2009) explica la presencia de cabello natural como un añadido posterior sin aportar datos que lo justifiquen, sin embargo debido a las analogías formales del Cristo del Otero con los otros cristos estudiados no hay razón para sospechar que sea así, independientemente de que se hayan podido reponer en épocas posteriores, como consecuencia de su deterioro.

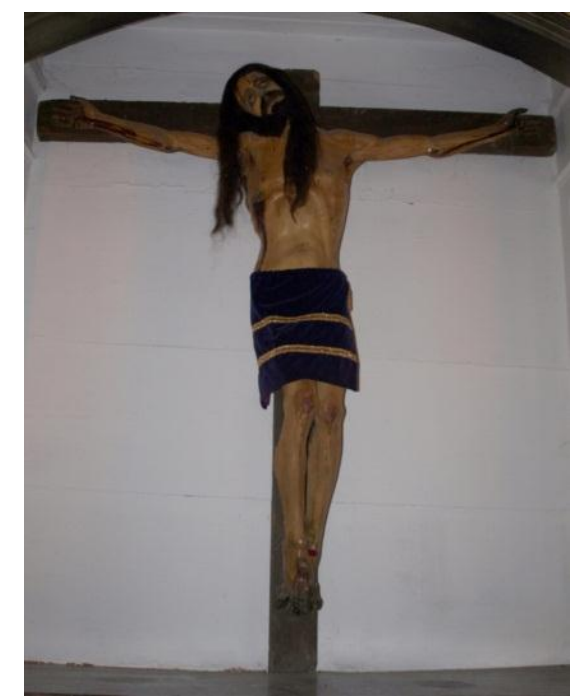

Figura 7. Santo Cristo del Otero $(163 \times 153 \times 30 \mathrm{~cm})$ Ermita del Otero, Palencia. 


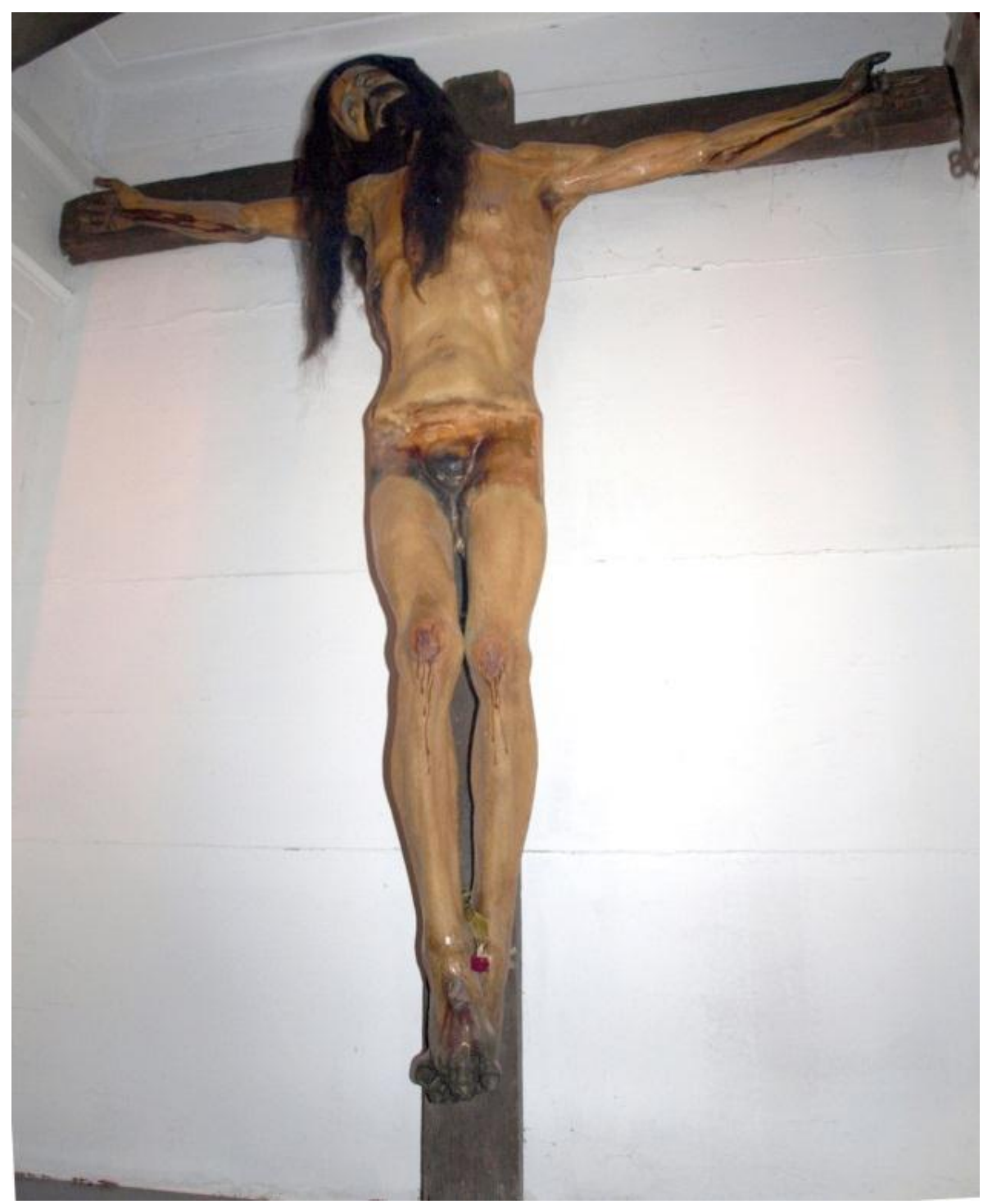

Figura 8. Aspecto del Santo Cristo del Otero sin faldellín, marcas dejadas por el sistema constructivo con tela encolada.

El Santo Cristo del Otero es prácticamente idéntico al Cristo de la Misericordia, y muy similar a los otros de Villaquejida, Sahagún y Salamanca, a pesar de las transformaciones que ha sufrido a lo largo de su historia como el embotamiento y difuminado de detalles por superposición de estratos de policromía, o la pérdida del perizonium.

\section{Conclusiones}

El haber considerado la tela encolada y el cabello natural como añadidos posteriores de época barroca, ha supuesto que se los haya juzgado más severamente: "el afán de realismo llevó a emplear recursos de dudosa licitud, como son el empleo del trapo encolado para las partes más finas de los ropajes, ojos de cristal y aún cabelleras postizas, limitadas éstas a imágenes de poca calidad artística; pero el abuso de tales recursos técnicos contribuyó a la decadencia de la escultura" (Gómez-Moreno 1963: 18). 
Pero el grupo de crucificados estudiados en este artículo son obras de notable calidad artística, incluyendo el uso de tales recursos. Todos ellos presentan una serie de elementos comunes que los identifican y pueden servir para adscribir a este conjunto cualquier otra obra que reúnan las mismas características:

- $\quad$ Están tallados en madera y policromados.

- $\quad$ El perizonium se realiza con tela encolada mientras que el lazo anudado puede ser de la misma tela o bien estar tallado en madera. Si bien han podido sufrir intervenciones y reparaciones, el uso de la tela encolada y el cabello natural pensamos que se trata de materiales y técnicas contemporáneas a las obras.

- $\quad$ El paño de pureza de tela encolada tiene pliegues finos, y ofrece un aspecto de mojado y pegado al cuerpo. Están policromados con temple blanco, y en ocasiones decorados en los orillos. El tejido empleado es tafetán de lino, apretado y de hilo medio/fino.

- Los cristos tienen cabello natural en la cabeza y/o en la barba, que van adheridos directamente sobre la preparación o la policromía. Parecen elementos originales a pesar de que hayan podido ser repuestos o eliminados posteriormente, y en ningún caso parecen añadidos posteriores.

- Tienen una anatomía dura, con la musculatura muy pronunciada, marcándose tendones y venas.

- La carnación original es de una tonalidad que varía del rosado hasta el gris con cierta tendencia cetrina en algunas zonas, además de numerosos latigazos y heridas repartidas por toda la piel.

- La corona de espinas, escultórica o natural, es un elemento elaborado de forma independiente que se coloca sobre la peluca.

- $\quad$ Están datados entre finales del siglo XV y el primer tercio del siglo XVI, algunos están atribuidos pero no documentados.

- $\quad$ Son imágenes que mantienen su función originaria para el culto, y han estado rodeadas de hechos milagrosos.

- Son de tamaño natural, con medidas muy similares.

Para intentar explicar el significado del uso de la tela encolada y del cabello natural, se aportan algunas teorías. Habitualmente se han aducido motivos de orden práctico: aligeramiento de peso, carencia de recursos técnico-artísticos para resolver los pliegues con talla, ahorro en tiempo y costes. Pero obviamente no responden a la cuestión, pues aquí no hay que aligerar peso, la pericia y la maestría escultórica en la talla del drapeado es evidente, y tampoco ha supuesto menor coste de ejecución. La elección tanto de la tela encolada como del cabello natural hay que buscarlo en una voluntad expresiva de su autor. Suponen un esfuerzo para expresar naturalismo, aportando una dosis de realidad, al adherirse y articularse con el resto de la escultura. En este afán, la representación de lo divino en estos crucificados se dota de una apariencia humanizada, cercana y tangible, y "por medio de esa apariencia profana la identidad del suceso o rito religioso quedará legitimado como suceso verídico."(Fernández 2009), dejan de ser re-presentación, para convertirse en simulacro de lo divino. 


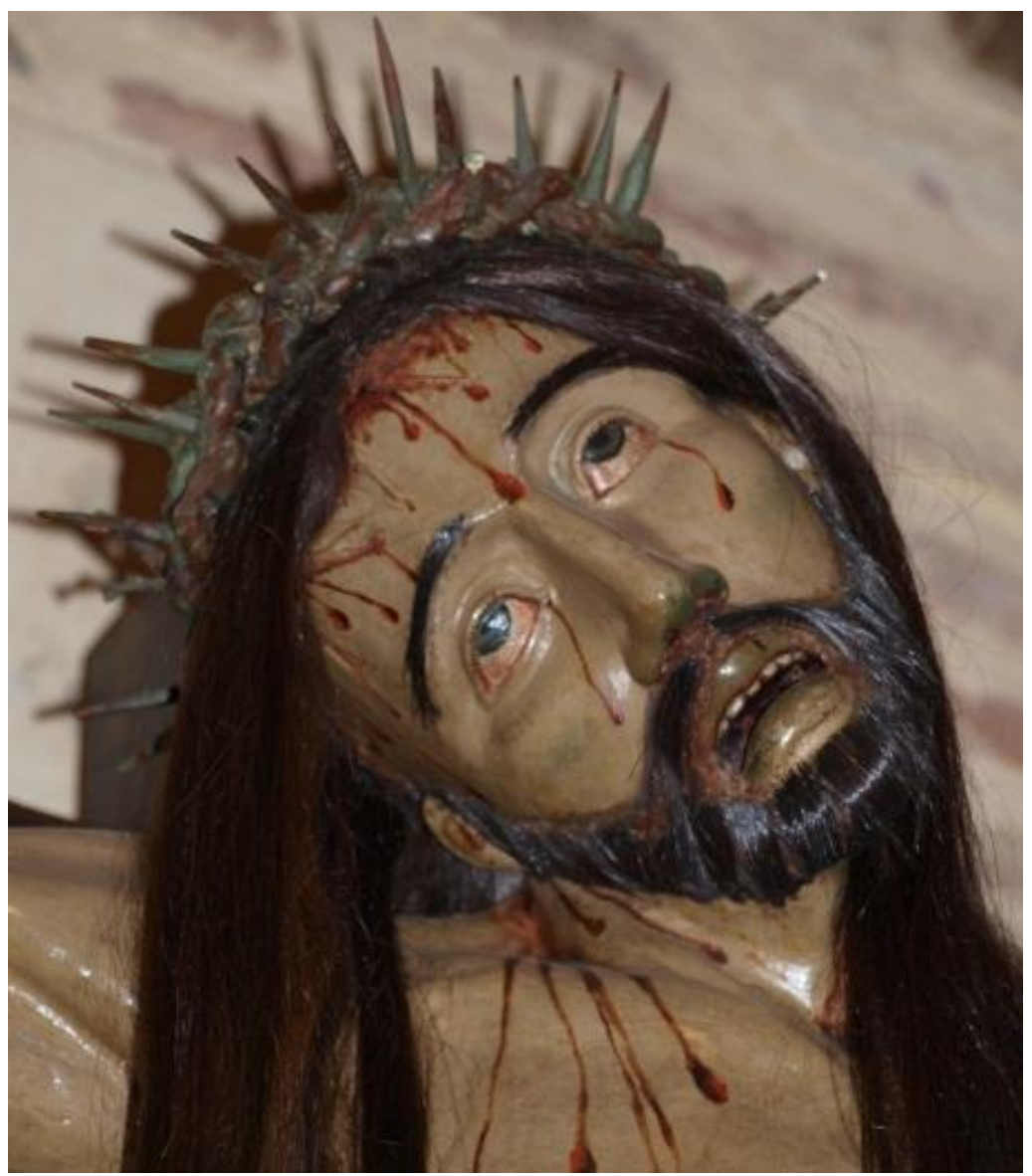

Figura 9. Detalle de la cabeza del Cristo de la Agonía. Se aprecia el empleo de cabello natural en las cejas, barba y cabellera.

La tela encolada lleva implícito el efecto del tiempo detenido, de la perpetuación de un instante a causa del encolado. Las telas en las prendas reales están sometidas a continuos movimientos y transformaciones en formas, pliegues y volúmenes, por efecto de la gravedad, tipo de fibra, hilatura, ligamento, peso y grosor del tejido que las conforman. En cambio, la tela encolada consigue fijar esas formas como en una instantánea volumétrica, y ya no se verá afectada en su forma aunque se mueva, o manipule, o por influencia del entorno.

Resulta desconcertante que se emplee en un mismo paño de pureza dos materiales y técnicas diferentes, madera tallada en el lazo anudado y el resto con tela encolada, si lo que se busca es naturalismo en el conjunto de la escultura. De nuevo hay una razón expresiva: las rectas, ángulos y curvas de los pliegues tallados aportan cierta esquematización y orden, mostrándolos vaporosos, y alzándose contra la gravedad. Es una metáfora de la eternidad y la divinidad de Cristo Crucificado, efecto que se logra técnicamente mejor con la madera tallada, pues la tela encolada cede a la gravedad y la caída del tejido. Es el caso del Cristo de la Salud de Alba de Tormes, cuyo paño de pureza está tallado íntegramente en madera para resaltar el aspecto eterno e idealizado de lo divino. En contraste, se sitúa la humanizada tela encolada de líneas vacilantes y nerviosas, que a veces son impredecibles, empapándose y adhiriéndose al cuerpo, cayendo y cediendo a la gravedad, en una instantánea en la que parece que el tiempo se ha detenido, como en el Cristo de la Misericordia, donde el perizonium está completamente hecho de tela encolada y muestra una humanización de 
Cristo exacerbada, acercándolo al aquí y al ahora. Y entre ambas soluciones plásticas se encuentran los perizonios del Cristo de la Agonía Redentora, el Bendito Cristo de Villaquejida, el Cristo de la Agonía y el Santo Cristo del Otero, donde se optó por realizar el paño de pureza en tela encolada en un intento de acercamiento y de humanización -junto al empleo de cabello natural y de barba postiza-, mientras que el lazo anudado se realizó en madera tallada, para contrarrestar un exceso de humanización y por contraste mantener un cierto grado de idealización y eternidad en la representación sagrada.

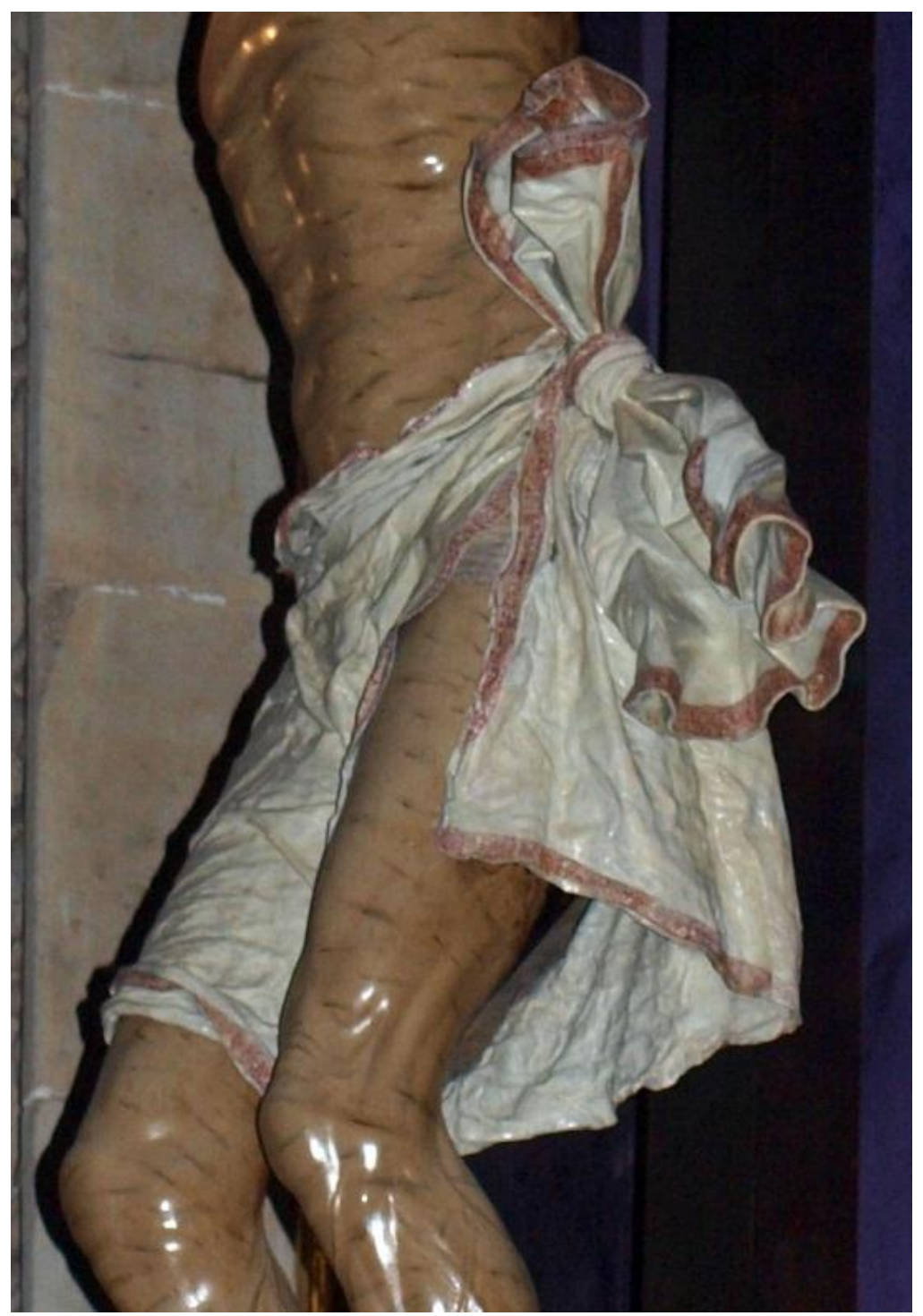

Figura 10. Coexistencia de tela encolada y de drapeado tallado en madera en el perizonium del Cristo de la Agonía Redentora.

No existen pruebas que indiquen en estos cristos que la tela encolada ${ }^{17}$ y el cabello natural pudieran haber sido aditamentos barrocos, pues a pesar de las dificultades en el estudio de los distintos estratos de policromía, los datos obtenidos hasta ahora en su estudio indican que puedan ser originales: 
- Bajo la tela encolada, en los casos en que se ha podido estudiar el interior total o parcialmente, se encuentra la madera tallada con formas anatómicas, y sin preparación ni policromía. Tampoco hay señales o indicios de retallados posteriores - por cambio de gusto $\mathrm{u}$ otros motivos-, lo que hace suponer que se concibió de esa manera para recibir encima la tela encolada, para posteriormente policromar el conjunto. Una transformación posterior podría haberse dado de manera aislada en alguno de los cristos, pero resultaría muy llamativo que se hubiera efectuado en todos los casos estudiados con el mismo resultado y empleando las mismas técnicas y materiales, ya que hay una distancia física que los separa, y ninguna relación entre ellos.

- Los estratos de preparación blanca de la policromía considerada original están al mismo nivel estratigráfico tanto en la tela encolada como en las partes talladas, sin encontrar incompatibilidades cronológicas.

- Las cabezas que tienen cabello natural se tallaron lisas, y no hay indicios de que fueran de otra manera y que se alisaran posteriormente, pues la preparación blanca del estrato considerado original se encuentra sobre la talla lisa.

- $\quad$ El cabello natural y las barbas postizas se encuentran adheridas sobre dicho estrato blanco de preparación, lo que los hace coetáneos de la policromía considerada original.

Debido a las enormes similitudes de las obras analizadas, se podría pensar que fueran obras de un mismo taller, e incluso establecer la hipótesis de que el Cristo de la Salud sea el modelo inicial en el que se basaron los otros cristos estudiados, por su gran calidad artística y por el hecho de que en él no se empleara tela encolada: bien pudiera ser obra de un artista centroeuropeo, traída o realizada en España, pero que desconocía el uso de la tela encolada, técnica ya empleada en el oeste de la actual Castilla y León, y que artistas locales usaron como adaptación local al copiar el modelo inicial de tipo centroeuropeo. Entre ellos pudiera encontrarse a Juan de Balmaseda, como han apuntado las atribuciones en algunos de los cristos, o su taller, y por ello se aprecian ciertas diferencias técnicas entre ellos. Hay que descartar la hipótesis de la dificultad técnica por parte del autor o autores de los demás crucificados, como lo demuestra la pericia mostrada en la talla del resto del perizonium, y del conjunto de la escultura. Tampoco es plausible la hipótesis de la dificultad económica, pues el uso de tela encolada no supone un ahorro sustancial de costes de producción o ejecución que justifique su elección para parte del paño de pureza. Por tanto, creemos que se trata de copias posteriores, y que a su vez muestran la expresión de un nuevo gusto, empleando recursos que tendrán su auge y completo desarrollo sobre todo con la imaginería barroca ${ }^{18}$.

En cualquier caso, se trata de técnicas y materiales que se han empleado en la escultura desde el siglo XV y forman parte de su materialidad e integridad, y que por tanto hay que estudiarlas, considerarlas y respetarlas, revisándolas desde la Historia del Arte para su mejor conocimiento y para evitar intervenciones de conservación y restauración que consideran la tela encolada y el cabello natural aditamentos no originales susceptibles de ser eliminados, corriendo el riesgo de que desaparezcan los pocos vestigios de un acervo técnico y artístico muy notable sobre todo en esta región.

Sin embargo, estos resultados pueden considerarse una primicia de un trabajo de investigación en cuya continuación se espera profundizar ampliando la documentación bibliográfica y verificando las hipótesis expuestas con otros análisis técnicos complementarios. 


\section{Notas}

[1] Forma parte de las investigaciones efectuadas por el autor para su tesis doctoral sobre este tema en la Universidad de Castilla-La Mancha.

[2] Ambas son objeto de estudio inédito en la citada tesis, en el que se expone el uso de la tela encolada en épocas tan tempranas.

[2] Desfila con la Real Cofradía Penitencial de Cristo Yacente de la Misericordia y de la Agonía Redentora.

[3] Las medidas que se dan para todos los crucificados estudiados son sin cruz.

[4] Informe de intervención de Ma Isabel Pantaleón Rodríguez, 2007. Archivo del CCRBC de la Junta de Castilla y León.

[5] Restaurado en 1996 por la empresa Uffizzi de Salamanca, y en 2007 por Ma Isabel Pantaleón Rodríguez. Los restos de barba ya no aparecen después de 1996.

[6] En 1996, los clavos fueron sustituidos por espigos de madera. En 2007 se colocó en la parte superior un espigo de haya de $12 \mathrm{~cm}$ de longitud y $8 \mathrm{~mm}$ de diámetro, y en la parte inferior otro de $6 \mathrm{~cm}$ de largo y $5 \mathrm{~mm}$ de diámetro. Archivo del CCRBC de la Junta de Castilla y León.

[7] En el Catálogo Monumental de la Provincia de Salamanca, figura como del siglo XV, procedente del Monasterio de San Leonardo de la orden Jerónima en Alba de Tormes, donde "debió gozar de fama, puesto que el Claustro de la Universidad de Salamanca envió una comisión a verlo en 1510 a fin de hacer otro para su capilla". Esa copia bien pudiera tratarse del de la Agonía Redentora.

[8] Véase la obra de Tilman van der Burch (c.1430-1495), Anton Pilgram (c.1450-1515), o Tilman Riemenschneider (c.1460-1531), entre otros, donde los aspectos formales tienen parecidos más que evidentes.

[9] Realizada por José Luis González Santos en 2007. En el Archivo Parroquial de Villaquejida se pudo consultar el Informe de Restauración.

[10] De acuerdo a los datos reflejados en el citado Informe de Restauración consultado.

[11] Es lo que queda del Convento de Franciscanos abandonado durante la Desamortización en 1835, y que actualmente se conoce como Iglesia-Santuario de la Peregrina.

[12] Se aprecian en las fotografías hechas por la restauradora Marta Eva Castellanos en 2007, que nos facilitó para este estudio. También aparecen en la policromía original del Cristo de la Misericordia, por lo que pudiera descartarse como aditamento barroco.

[13] Informe de intervención de Raquel de los Mozos, 2005. Archivo del CCRBC de la Junta de Castilla y León.

[14] Blázquez Vicente lo relaciona con el de la Agonía Redentora de Salamanca, y basándose en ello lo atribuye a Balmaseda. (Blázquez 2001: 27-29).

[15] Portela Sandoval también lo atribuye a Balmaseda, pero no así el cabello natural, que "desvirtúa un tanto su calidad", creyendo que es un añadido posterior. (Portela 1977: 137)

[16] Seguramente se perdió en un incendio, como lo demuestra el ennegrecimiento en la madera desnuda y en la policromía de la zona pélvica. Esta pérdida es anterior a 1874, fecha de un inventario de 
la ermita en el que figuran "Siete toneletes del Divino Cristo, de varias clases y colores"; hacía tiempo que se vestía la imagen por la cantidad de ropa que tenía en esa fecha. (San Martín 1985: 189-195)

[17] Los aspectos técnicos, materiales y procedimentales de la tela encolada no se han abordado en el presente artículo, pues se plantean como una continuación del trabajo de investigación del que se presentan estas primicias.

[18] El estudio de estos recursos en la imaginería barroca es objeto de la investigación que el autor se encuentra elaborando.

\section{Bibliografía}

BLÁZQUEZ VICENTE, F. J. (2001). "Santísimo Cristo de la Agonía Redentora. Estudio Histórico Artístico. La cuestión de su autoría". Revista Cruz de Guía. Salamanca: Cofradía de Cristo Yacente de la Misericordia y de la Agonía Redentora. 20: 26-29.

CAMÓN AZNAR, J. "La escultura y la rejería española en el siglo XVI". En Summa Artis, (vol. 18, pp. 156-164). Madrid: Espasa Calpe.

FERNÁNDEZ MORATE, S. (2009). Cristo del Otero: leyenda, tradición e historia. Palencia: Ayuntamiento de Palencia.

FERNÁNDEZ SÁNCHEZ, J. A. (2009) "Apariencia y atuendo en la imagen sagrada de vestir: el caso de Murcia". En Congreso Internacional Imagen Apariencia, Murcia: Servicio de Publicaciones de la Universidad de Murcia. http://congresos.um.es/imagenyapariencia/imagenyapariencia2008/paper/view/2181. [consulta: 29/3/2012]

GÓMEZ GARCÍA, M.C. Disposición del paño de pureza en la escultura del Cristo Crucificado entre los siglos XII y XVII. Memoria para optar al grado de Doctor, bajo la dirección de Ana Ma Macarrón Miguel. Facultad de Bellas Artes, Universidad Complutense de Madrid, 2007. http://eprints.ucm.es/7511/. [consulta: 26/9/2012]

GÓMEZ PÉREZ, E. (2005). La Semana Santa en la ciudad de Palencia. Cofradías, pasos, procesiones y tradiciones. Palencia: Ayuntamiento de Palencia.

GÓMEZ-MORENO, M. (1925).Catálogo Monumental de la Provincia de León. Madrid: Ministerio de Instrucción Pública y Bellas Artes.

GÓMEZ-MORENO, M. (1967). Catálogo Monumental de España. Provincia de Salamanca, 1901-1903. Madrid: Servicio Nacional de Información Artística.

GÓMEZ-MORENO, M. E. (1963). “Escultura del siglo XVII”. En Ars Hispaniae. Historia Universal del Arte Hispánico (vol. 16). Madrid: Editorial Plus Ultra.

PARRADO DEL OLMO, J. M. (1961). "La imagen del Cristo de Villaquejida". Revista Tierras de León. León: Diputación Provincial de León. 36-37: 150-151

PORTELA SANDOVAL, J. (1967). La Escultura del siglo XVI en Palencia. Colección Pallantia 4. Palencia: Diputación Provincial de Palencia.

RODRÍGUEZ RUBIO, T. (1922). Recuerdos y bellezas de Alba de Tormes. Sevilla: Autor.

SAN MARTín PAYO, J. (1985). El Cristo del Otero y Santo Toribio. Palencia: Diputación Provincial de Palencia.

SÁNCHEZ Y SÁNCHEZ, D. (1993). Catedrales, santuarios y ermitas de Salamanca: La Catedral Nueva de Salamanca. Salamanca: Autor 
SPERANZA, L. (2007). (A cura di) La scultura lignea policroma: ricerche e modelli operativi di restauro. Le antologie di "OPD Restauro". Firenze: Centro Di.

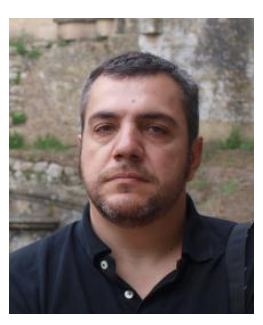

Francisco Javier Casaseca García

fcojaviercasaseca@gmail.com

Licenciado en Bellas Artes en la Universidad Complutense de Madrid, especialidades de Pintura y de Restauración. Es restaurador de obras de arte y profesor de conservación y restauración de escultura en la Escuela de Arte y Superior de Conservación y Restauración de Valladolid.

Artículo recibido el 30/03/2012

Artículo aceptado el 28/09/2012 